\title{
CHARACTERIZATION OF SEDIMENTS FROM THE FUNDÃO DAM
}

FAILURE

\author{
M. T. D. ORLANDO ${ }^{a}$, C. V. G. T. RANGEL ${ }^{\text {b }}$, E. S. GALVÃO ${ }^{a}$, C. G. P. ORLANDO ${ }^{a}$, A. C. \\ BASTOS and V. S. QUARESMA ${ }^{\text {a }}$ \\ ${ }^{\text {a } U n i v e r s i d a d e ~ F e d e r a l ~ d o ~ E s p i r i t o ~ S a n t o, ~ V i t o ́ r i a, ~ B r a s i l . ~}$ \\ ${ }^{b}$ Universidade Federal do Sul da Bahi), Porto Seguro, Bahia, BA, Brazil
}

\section{RESUMO}

$\mathrm{O}$ acidente com a barragem de Fundão, Mariana, MG, lançou toneladas de rejeitos de minério de ferro no sistema fluvial do Rio Doce. Apesar da composição natural dos sedimentos fluviais, caracterizada por fases minerais relativamente comuns como quartzo, muscovita, caulinita e illita e até mesmo certos teores de hematita e goethita, é importante verificar a abundância de hematita e magnetita após o acidente. Os sedimentos pós-acidente da cidade de Mariana foram analisados por difração de raios X Syncrotron, EDXRF e suscetibilidade AC. Foi encontrado um teor significativo de ferro, que não é encontrado nos sedimentos naturais da mesma região antes do acidente com a barragem de Fundão, Mariana, MG. Algumas fases cristalinas encontradas são originadas de processos de processamento na indústria de extração mineral, pois seus cristais são de origem sintética (não encontrados na natureza).

Palavras chaves: Sincrotron DRX, Fluorescência RX, AC Susceptibilidade Magnética.

\begin{abstract}
The accident with the Fundão dam, Mariana, MG, launched tons of iron ore tailings into the Rio Doce river system. Despite the natural composition of the river sediments, characterized by relatively common mineral phases such as quartz, muscovite, kaolinite and illite and even certain hematite and goethite contents, it is important verify the abundance of hematite and magnetite after the accident. The Mariana city post-accident sediments were analyzed by Syncrotron X-ray diffraction, EDXRF and AC Susceptibility. It was verified a significant iron content, which is not founded in the natural sediments in the same region before the accident with the Fundão dam, Mariana, MG. Some crystalline phases detected are originated from processing processes in the mineral extraction industry, as their crystals are of synthetic origin (not found in nature).
\end{abstract}

Keywords: Synchrotron DRX, EDXRF, AC Magnetic Susceptibility

\section{INTRODUCTION}

The accident with the Fundão dam, Mariana, MG, launched tons of iron ore tailings into the Rio Doce river system. After a few days, the ore contamination plume reached the mouth, reaching the adjacent marine region. In a recent study Almeida et al [1] performed the characterization of the iron ore from the accident and spreading in the Rio Doce basin. Despite the natural composition of the river sediments, characterized by relatively common mineral phases such as quartz, muscovite, kaolinite and illite and even certain hematite and goethite contents, it is important verify the abundance of hematite and magnetite after the accident. Taking this into account, our working group used three different techniques to verify the abundance of crystalline phases present in post-accident sediments.

\section{MATERIALS AND METHODS}

X-ray diffraction measurements of the samples were performed at the Sincrotron National Light Laboratory at the National Center for Energy and Materials (CNEM-LNLS) in 


\section{Blucher Proceedings \\ $9^{\text {th }}$ WORKSHOP OF CRYSTALLOGRAPHY APPLIED TO \\ MATERIALS SCIENCE AND ENGINEERING}

Meaípe, Guarapari - ES, Brasil, May 2019

\section{Blucher}

Campinas - Brazil. The measurements were taken on line XRD1 (Proposals 20170383 and 20170108 ) using a wavelength of 0.103287 (2) $\mathrm{nm}$. Figure 01 shows the beam line XRD-1.

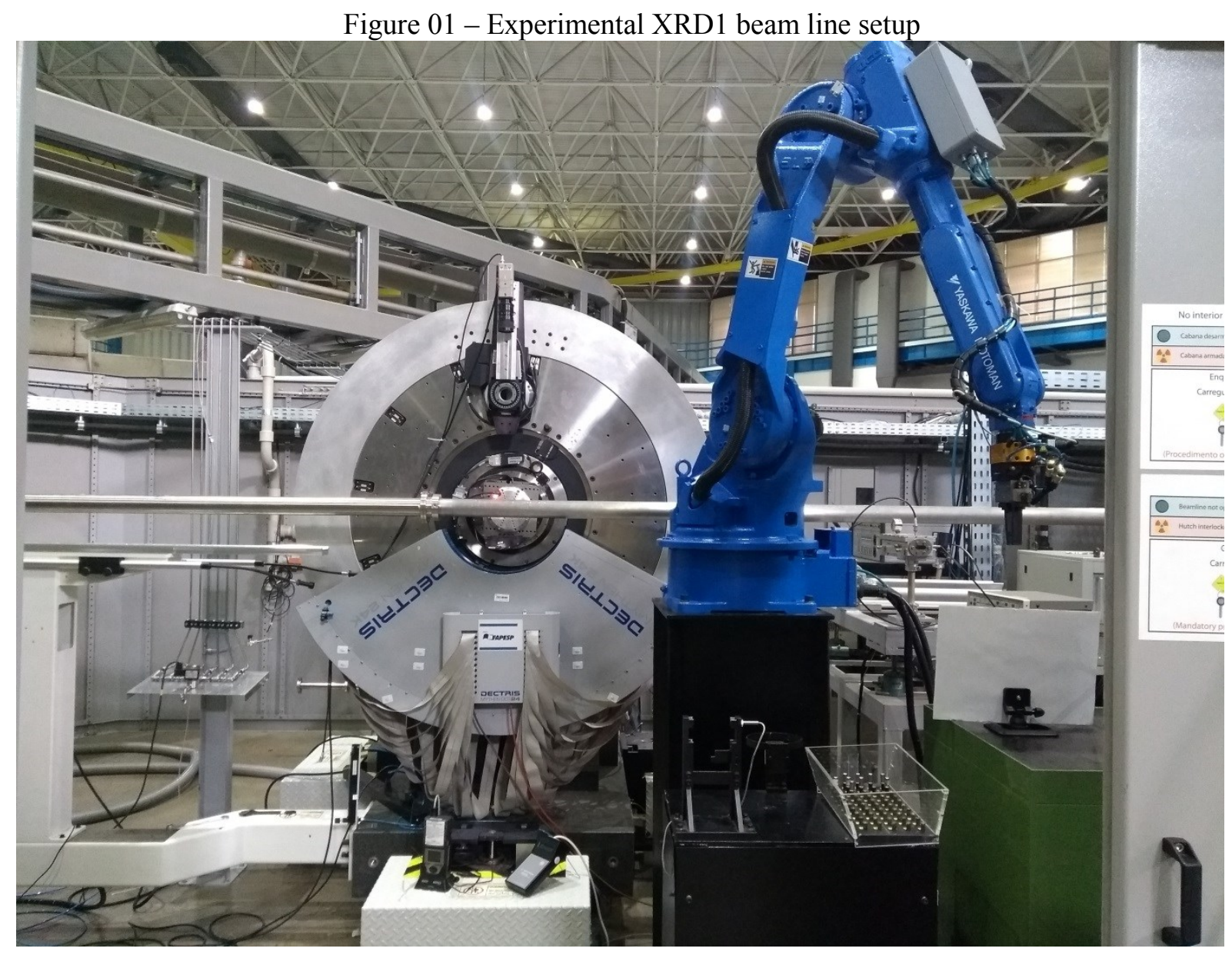

All samples in this work presented the same avarege particle size. The sediments were grounded and sieved down to particle sizes were smaller than 53 micrometers. Wavelength calibration was performed with the NIST silicon standard. Measurements were made by transmission using a transparent capillary $0.5 \mathrm{~mm}$ in diameter.

Elemental analysis was carried out by an energy dispersive X-ray fluorescence spectrometer (EDXRF), model EDX-720 (Shimadzu, Japan). Metallic elements ranging from $\mathrm{Na}$ to $\mathrm{U}$ were scanned for detection and measurement. The scan was performed by two channels (Na-Sc and Ti-U). All samples (filters and bulk) were measured using a rhodium X-ray tube, $15-50 \mathrm{kV}, 1000$ (auto) $\mu \mathrm{A}, 500$ seconds of integration by channel and a $\mathrm{Si}(\mathrm{Li}$ ) detector. However, samples onto cellulose filters were analysed under vacuum medium. Laboratory filter blanks were also analyzed to evaluate analytical bias. The quantification was performed by calibration curves made by analysis of 47 certified reference materials (CRM) ranging from 40.3 to $58.8 \mu \mathrm{g} \mathrm{cm}^{-2}$ deposited on thin mylar membranes (Micromatter, USA) ranging from low-Z to high-Z elements (Na to $\mathrm{Rg}$ ).

Magnetic susceptibility measurements of the samples were made at the UFES High Pressure Laboratory (PRESLAB) using an AC system. A simplified scheme of this home assembly is shown in figure 02 . 


\section{Blucher Proceedings \\ $9^{\text {th }}$ WORKSHOP OF CRYSTALLOGRAPHY APPLIED TO \\ MATERIALS SCIENCE AND ENGINEERING}

Meaípe, Guarapari - ES, Brasil, May 2019

Figure 02 - Experimental schema of homemade ac magnetic susceptometer.

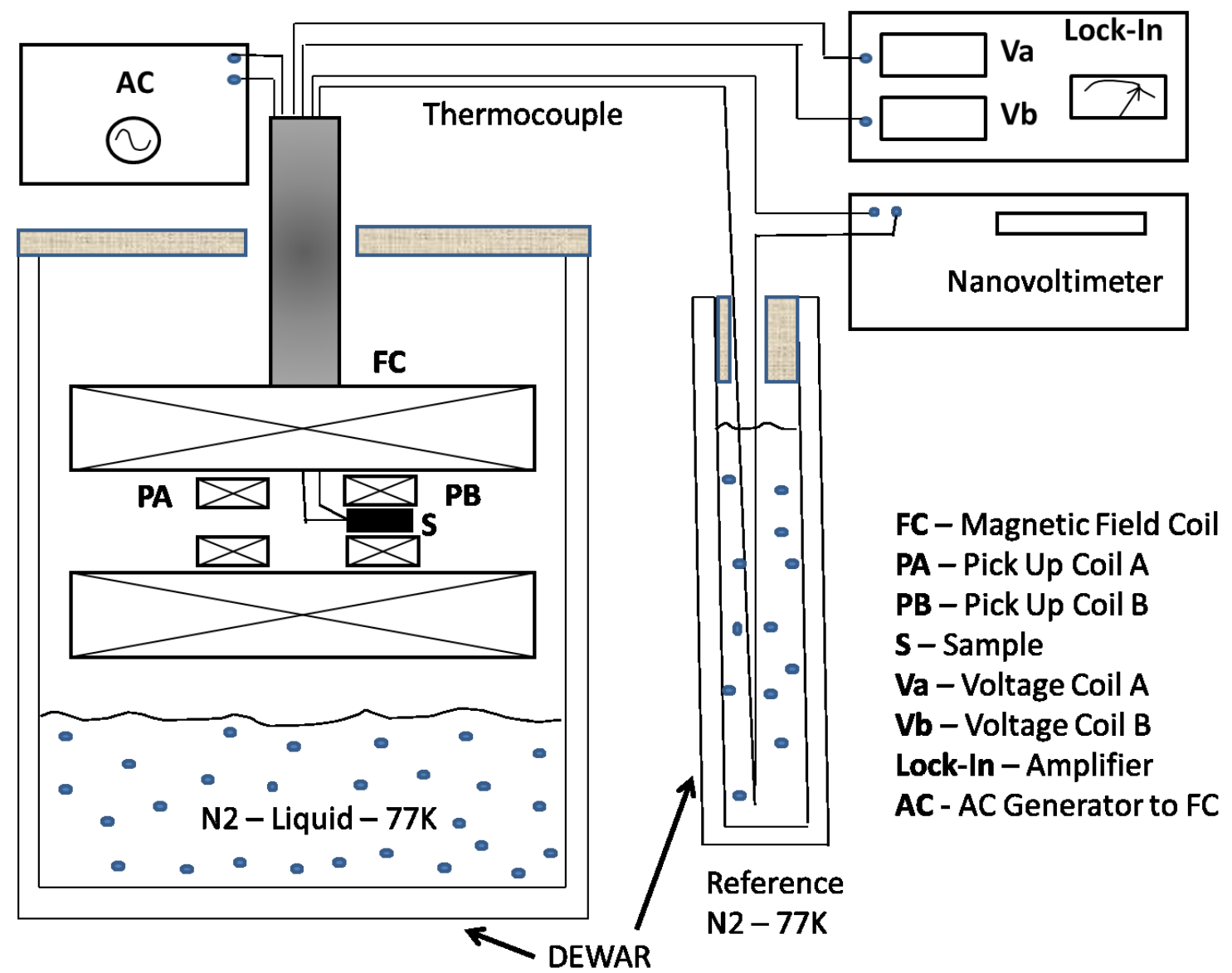

The assembly presents the following components: one field coil to apply magnetic field, two secondary pick up coils and a lock-in amplifier. The ac generator creates a current in the field coil, which creates an alternating magnetic field in the two inner secondary coils. The secondary coils are identical, but have been installed with opposite winding directions so that the potential difference $\mathrm{Vb}$ in one of the coils is equal in modulus and the opposite direction of the potential difference $\mathrm{Va}$ of the other secondary coil. Thus, the resulting value read from the Lock-in must be null. However, if a magnetic material is placed inside one of the coils, the sum of the two potential differences will

be nonzero. In this assembly the Lock-in is responsible for measuring this signal, the voltage difference $\mathrm{Va}-\mathrm{Vb}$. The setup accuracy is $1 \mathrm{ppm}$.

The outer coil (FC) generates an oscillating magnetic field given by:

$$
B=B_{0} \cos (\omega \cdot t) .
$$

Thus, considering A the area of the sensor coils, we will have:

$$
V=-\frac{d \phi}{d t}=-A \frac{d B}{d t} \Rightarrow V=A \cdot \omega \cdot B_{0} \cdot \operatorname{sen}(\omega \cdot t)
$$

Thus, the voltages in the secondary coils are:

$$
V_{a}=A \cdot \omega \cdot B_{0 a} \cdot \operatorname{sen}(\omega \cdot t) \text { e } V_{b}=A \cdot \omega \cdot B_{0 b} \cdot \operatorname{sen}(\omega \cdot t)
$$




\section{Blucher Proceedings \\ $9^{\text {th }}$ WORKSHOP OF CRYSTALLOGRAPHY APPLIED TO \\ MATERIALS SCIENCE AND ENGINEERING}

Meaípe, Guarapari - ES, Brasil, May 2019

So, since the sensor coils are coiled in phase opposition, we have:

$$
\begin{aligned}
& V_{a}-V_{b}=\Delta V=\left(B_{0 a}-B_{0 b}\right) \cdot A \cdot \omega \cdot \operatorname{sen}(\omega \cdot t) ; \\
& \frac{\Delta V}{V}=\frac{\left(B_{0 a}-B_{0 b}\right) \cdot A \cdot \omega \cdot \operatorname{sen}(\omega \cdot t)}{B_{0} \cdot A \cdot \omega \cdot \operatorname{sen}(\omega \cdot t)}=\frac{B_{0 a}-B_{0 b}}{B_{0}}
\end{aligned}
$$

Finally,

$$
\begin{gathered}
\frac{\Delta V}{V}=\frac{B_{0 a}-B_{0 b}}{B_{0}}=\frac{\mu \cdot H-\mu_{0} \cdot H}{\mu_{0} \cdot H}=\frac{\mu_{0}\left(1+\chi_{m}\right)-\mu_{0}}{\mu_{0}} \\
\frac{\Delta V}{V}=\frac{V_{a}-V_{b}}{V}=\chi
\end{gathered}
$$

We see that from a simple relationship between the tensions involved we obtain the susceptibility of the material. Dividing $\chi$ by the density of the sample we have $\chi_{\mathrm{m}}$, magnetic susceptibility.

$$
X m=\frac{X}{\rho}
$$

In this setup magnetic susceptibility is only calculated from measurements of variation of the coil voltage induced, however one knows that it depends on other parameters involved, such as frequency and temperature. Taken into account, the measuring setup also records the temperature and current values in the generator coil.

The readings of the measured parameters are archived on the computer by the same program that automates the susceptometer. This software was also developed by PRESLAB and

allows you to generate a file to be read in any graphic program that you want to analyze or process data.

The mounting of this apparatus is ideal for temperature sensitive magnetic susceptibility measurements. Temperature variation cannot be controlled and is thus obtained by the natural evaporation of liquid nitrogen that cools the susceptometer (and the sample contained therein). The sample is cooled in a few minutes to reach liquid nitrogen temperature (around $77 \mathrm{~K}$ ), but the heating phase is quite slow (due to the susceptometer engineering itself that stores nitrogen in an almost adiabatic compartment) and may take several hours

Then, it is possible to measure the magnetic susceptibility of the sample from $77 \mathrm{~K}$ to room temperature. If necessary the sample can be heated to a temperature of $373 \mathrm{~K}$. 


\section{Blucher Proceedings \\ $9^{\text {th }}$ WORKSHOP OF CRYSTALLOGRAPHY APPLIED TO \\ MATERIALS SCIENCE AND ENGINEERING}

Meaípe, Guarapari - ES, Brasil, May 2019

\section{RESULTS AND DISCUSSION}

A representative measure of X-ray diffraction at LNLS - CNPEM station XRD1 of the sediment samples found in the Mariana city from the Fundão dam failure is shown in figure 03.

Figure 03 - Synchrotron X-ray diffraction pattern of sediment from city Mariana.

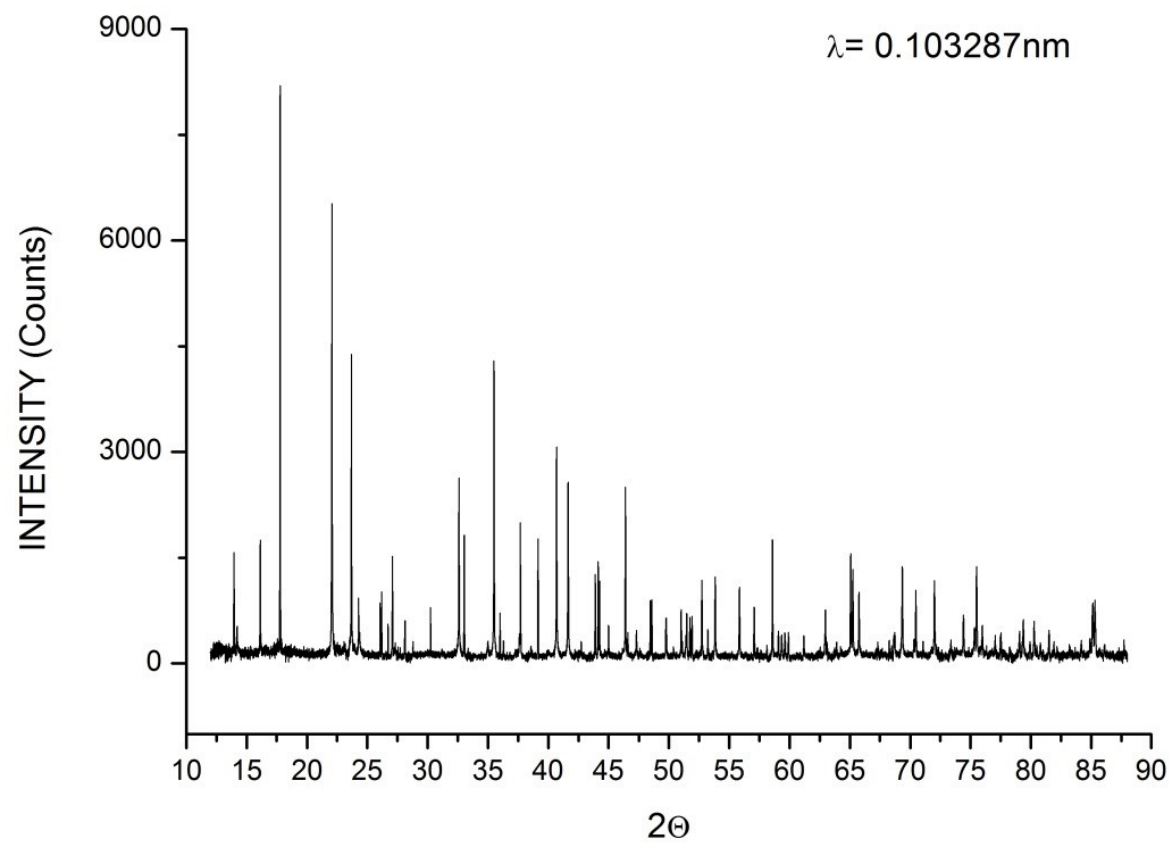

It was used a PDF-2 program to identify the crystallographic phase in the representative Mariana sediment sample. The Table I indicate crystallographic phases candidates presents in this difratogram, taken into account the $90 \%$ as confidence threshold.

Table I - Crystallography phase content present in the Mariana sediment representative sample

\begin{tabular}{|l|c|c|}
\hline Phase & PDF number & \% volumetric \\
\hline Hematite - F2O3 & $33-664$ & 19.2 \\
\hline Magnetite - FeFe2O4 & $19-629$ & 2.1 \\
\hline Quartz - SiO2 & $46-1045$ & 29.4 \\
\hline Potassium Sulfate - K2S2O8 & $32-846$ & 0.9 \\
\hline Anorthite - CaA12Si2O8 & $41-1486$ & 0.3 \\
\hline Manganese Silicon - MnSi & $42-1487$ & 0.4 \\
\hline Cesium Iron Sulfate Hydrate Cs2Fe(SO4)2!6 H2O & $20-402$ & 1.1 \\
\hline Szomolnokite - FeSO4!H2O & $45-1365$ & 38.0 \\
\hline Manganolangbeinite - K2Mn2(SO4)3 & $20-909$ & 8.6 \\
\hline
\end{tabular}

The crystallography phase content is associated with the crystal volume present in the sample total volume analyzed, taken into account the X-ray penetration and the spot size. As considering the density of each crystalline phase one can verify that this result is in agreement with the elemental analysis, which as carried out by an energy dispersive X-ray fluorescence spectrometer (EDXRF).

The Table II shows the elements from EDXRF present in the same representative Mariana city sediment sample. 


\section{Blucher Proceedings \\ $9^{\text {th }}$ WORKSHOP OF CRYSTALLOGRAPHY APPLIED TO \\ MATERIALS SCIENCE AND ENGINEERING}

Meaípe, Guarapari - ES, Brasil, May 2019

Table II - Elemental analysis from EDXRF of the elements present in the same representative Mariana sediment sample.

\begin{tabular}{|c|c|c|}
\hline Element & Mass (\%) & Line \\
\hline $\mathrm{Fe}$ & $72.3(1)$ & $\mathrm{Fe} \mathrm{Ka}$ \\
\hline $\mathrm{Si}$ & $20.7(2)$ & $\mathrm{Si} \mathrm{Ka}$ \\
\hline $\mathrm{Al}$ & $6.1(2)$ & $\mathrm{Al} \mathrm{Ka}$ \\
\hline $\mathrm{S}$ & $0.64(1)$ & $\mathrm{S} \mathrm{Ka}$ \\
\hline $\mathrm{Mn}$ & $0.16(1)$ & $\mathrm{Mn} \mathrm{Ka}$ \\
\hline $\mathrm{Cs}$ & $0.10(2)$ & $\mathrm{Cs} \mathrm{Ka}$ \\
\hline
\end{tabular}

As one can see, there exists stronger iron content in the representative sample. It was analyzed 10 samples. The statistical fluctuation of iron content was $10 \%$ in mass.

The AC magnetic susceptibility at room temperature of representative Mariana sediment sample was compared with Rio Doce river sediment after/before accident and standard compound $\mathrm{GdCl} 3$. The values are shown in the Table III.

Table III - Comparative ac magnetic susceptibility

\begin{tabular}{|c|c|}
\hline Compound & $\chi_{\mathrm{m}}\left(\mathrm{m}^{3} / \mathrm{kg}\right)$ \\
\hline $\mathrm{GdCl}_{3}(99.9 \%$ - Sigma $)$ & $1.3(1) \times 10^{-6}$ \\
\hline Rio Doce sediment before accident (2014) & $1.7(2) \times 10^{-6}$ \\
\hline Rio Doce sediment after accident $(2016)$ & $14.6(2) \times 10^{-6}$ \\
\hline Mariana sediment after accident $(2016)$ & $12.9(2) \times 10^{-6}$ \\
\hline
\end{tabular}

One can noted that the magnetic susceptibility of Rio Doce river sediment in 2016 presented an increment of approximately 10 times, as compared with Rio Doce river sediment before accident in 2015 .

\section{CONCLUSION}

The Mariana city sediments were analyzed by Syncrotron X-ray diffraction, EDXRF and AC Susceptibility. It was found a significant iron content, which is different in the natural sediments in the same region before the accident with the Fundão dam, Mariana, MG. Some crystalline phases found are originated from processing processes in the mineral extraction industry, as their crystals are of synthetic origin (not found in nature).

\section{ACKNOWLEDEGEMENTS}

The authors would like to acknowledge the Brazillian Synchrotron Light Source (LNLS, CNPEM - Campinas) for the technical support and use of its beam line XRD-1, Proposals 20170383 and 20170108, as well as to Brazilian Funding Agency CNPQ, CAPES and the Local Funding Agency FAPES for supporting this research.

\section{REFERENCES}

[1] Almeida, C. A, Oliveira, A. F., Pacheco, A. A., Lopes, R. P.,, Neves, A. A., and Queiroz, M. E. L. R., Characterization and evaluation of sorption potencial of the iron mine waste after Samarco dam disaster in Doce River basin - Brazil, Chemosphere, 209 (2018), 411-420. DOI:10.1016/j.chemosphere.2018.06.071 